\title{
Assessment of Roof Top BIPV Application of Sample Houses in Shah Alam
}

\author{
Ahmad Ridzwan Othman, Ahmad Tirmizi Rushdi \\ Faculty of Architecture, Planning and Surveying, \\ Universiti Teknologi MARA, 40450 Shah Alam, Malaysia \\ dwan_arc7@yahoo.com
}

\begin{abstract}
BIPV is an application where solar Photovoltaic modules are integrated into the building structures to produce electrical energy. It is silent, clean in operation, highly reliable and low maintenance. The purpose of the research is to assess BIPV application on the roof top of houses in Shah Alam area. Few samples were selected and important parameters were measured, and analysed to determine which roof form, orientations and PV types that influence the power generations. The average daily power generations range from $11.18 \mathrm{kWh} / \mathrm{kWp}$ to $29.18 \mathrm{kWh} / \mathrm{kWp}$ depending on the number of modules, PV type, roof inclination and location.
\end{abstract}

Keywords: Photovoltaic; Building Integrated Photovoltaic; power generation; orientation

eISSN 2398-4279 @ 2018. The Authors. Published for AMER ABRA cE-Bs by e-International Publishing House, Ltd., UK. This is an open access article under the CC BY-NC-ND license (http://creativecommons.org/licenses/bync-nd/4.0/). Peer-review under responsibility of AMER (Association of Malaysian Environment-Behaviour Researchers), ABRA (Association of Behavioural Researchers on Asians) and CE-Bs (Centre for EnvironmentBehaviour Studies), Faculty of Architecture, Planning \& Surveying, Universiti Teknologi MARA, Malaysia.

DOI: https://doi.org/10.21834/ajqol.v3i9.74 


\subsection{Introduction}

Photovoltaic are arrays of cells containing a solar photovoltaic material that converts solar radiation into direct current electricity (Wikipedia dictionary). Building integrated photovoltaic (BIPV) is the PV system that being applied within building component. Typically, an array is incorporated onto the roof or walls of a building. Arrays can also be retrofitted into existing buildings; in this case they are usually fitted on top of the existing roof structure.

Solar energy is the most abundant permanent source of energy in the world and has become an important environmental compatible source of renewable energy. The increase of electricity demand, the rigorous growth of building industry, and the highly potential of solar energy has made the application of BIPV (building integrated photovoltaic) technology in Malaysia as an important and wise approach. The BIPV technology not only create a sustainable impact to the buildings industry but also able to substitute part of the conventional electricity generators. In Europe and other developed countries, BIPV applications are proven reliable and in some cases are already cost-effective. However, in Malaysia BIPV technology has not really being explored and practice as a viable RE application. Many reasons lead to this phenomenon, among others are the lack of understanding on BIPV applications and the limited knowledge on how to utilize the BIPV technology among the users and developers. Another aspect that hinders BIPV application in Malaysia is the high investment costs and a longer payback period.

The first installation of grid-connected PV systems in Malaysia is dated back in 1998 with a total of $450 \mathrm{kWp}$ of grid-connected PV installed capacity. However, the current gridconnected PV application has not being explored the full potential of BIPV in the residential and commercial sectors. In a study by Sopian et.al. (2005), the estimated technical potential of BIPV in Malaysia based on available building surfaces is about 11,000 MWp. This technical potential capacity could generate about $12,000 \mathrm{GWh}$ of electricity annually that could cover $20 \%$ of the current electricity energy demand.

Based on the assessments of the local manufacturing and industry capabilities, indication clearly shows that Malaysia has a good potential to manufacture BIPV related products and components, such as the BIPV mounting mechanism, cables, connectors and inverters. Malaysia should take advantage of existing high technical skills, good education and well-established industries to move forward and enhance this BIPV related industries.

The overall prospect for business opportunities in the field of PV is very encouraging and need to be explored and practiced, especially in the residential sector. In the urban area where the residential development is dense, there are such a big amount of roof surfaces that can be capitalized through BIPV application.

\subsection{Statement of the Problem}

In Malaysia, the PV technology is well far behind compared to western countries even though the latter receive less annual solar exposure hours. Its application is limited in certain area such as expensive housing development and selected office buildings. Few issues arise when discussing about PV system like lack of awareness of conserving nature by the public and government. Many developers still not convince that BIPV can offer a fair payback 
period, and still thought that BIPV is very expensive and the application require highly skilled workers.

\subsection{Purpose of the Study}

The purpose of this study is to assess the level of BIPV application in Shah Alam and to determine which type of BIPV system is popular and commonly used in Malaysia. The main objectives of the study are:

- To determine the potential of BIPV application in Malaysia

- To measure how much the existing sample produce

- To highlight the positive and negative influential aspects so that the future application can be enhanced

\subsection{Significance}

The contribution of this study hopefully will give answer to the long debated issue on PV application and the effect of using it to the public and environment. The importance of this study is not only specific to the energy saving but also to enhance awareness among Malaysians towards the importance of protecting the environment. The findings from this research will also contribute the followings:

- Support the Malaysian BIPV Technology Application Project (MBIPV)

- Help to reduce $\mathrm{CO}_{2}$ production through increase applications

- To reduce overall price through bigger market

\subsection{Limitations}

Scope of the study is being narrowed down to one part of the building only which is the roof. Even though PV system can be implemented and incorporated onto building envelopes in many ways, such as the wall and roof, and can be either attached or detached from the building. The research is done only within the scope of BIPV application on roof top and how it influences the BIPV efficiency in relation with orientation, solar intensity, roof form and PV type. Building samples to be studied is within Shah Alam, Selangor.

\subsection{Literature Review}

The demand for solar electric power system has grown steadily over the last 2 decades. The need for reliable and low cost electric power in isolated areas of the world is the primary force driving the world-wide PV industry today. For a large number of applications, PV technology is simply the least-cost option. Significant growth in demand for PV systems is expected to occur in developing countries like Malaysia to meet the basic electrical needs of the peoples.

Haris (2008) in his study states that PV is best known as a method for generating electric power by using solar cells to convert energy from the sun into electricity. Solar energy is a huge power generator which remains largely untapped. Germany currently generates more solar energy than any other country in the world despite its northern location far from the equator and its relatively small population. The good news is that solar PV technology being 
a renewable energy alternative that is safe from any emission should be considered by Malaysia which has favorable climate condition.

\subsection{Photoelectric historical background}

During $19^{\text {th }}$ century, scientist discovered that when light was incident on liquids and metal cell surface, electrons were released. The explanation about the light can be converted into electricity also supported by Albert Einstein theory in 1905. Albert Einstein's theory about the law of "photoelectric effect" has become the foundation for the modern PV system. It defines as; electrons are released that are attracted towards a positive charged plate when light shone on a metal, thereby giving rise to photoelectric current. Albert Einstein won the Nobel Prize in physics for this photoelectric theory.

\subsection{Malaysian climate, solar intensity and illumination}

Malaysia is situated in the equatorial region with an average radiation of $4,500 \mathrm{kWh}$ per square meter, hence is an ideal location for large scale solar power installations. Considering that Malaysia gets an average 4.5 hours to 8 hours of free bountiful sunshine every day, the potential for solar power generation is very high. However, the real harnessing of this renewable energy source is way below its actual potential.

\subsection{Malaysia renewable energy issues and scenario}

Solar power projects have not yet taken off in a considerable manner in Malaysia as there is no coordination among existing agencies to publicize the information pertaining to the technology. Furthermore, limited technical support and incompetent services restrain the potential commercial and industrial establishments from venturing into this business. Many of them are not convinced about the reliability of supply from these units. Despite approvals from the concerned authorities, project execution gets delayed (Sucitra Sriram, 2006).

Most of the equipment required for solar power generation is still imported from USA, Europe or Japan. While the government provides exemption on import duty and sales tax for imported renewable energy equipment, the total cost of acquisition and installation still works out to be pretty high in comparison to other non-renewable forms of distributed generations. Further to the lack of awareness about this technology pushes up the cost for the aftermarket services. Thus there is a substantial opportunity for establishment of domestic production facilities of solar panels, inverters and protection systems, which will reduce the price and in effect stimulate the demand (Sucitra Sriram, 2006).

\subsection{Definition of BIPV}

BIPV is a building integrated photovoltaic where solar PV modules are integrated into the building structure. The integration could be made either installing the PV module on top of existing structure or by using the PV modules as part of the building materials. PV modules could also be used as building elements as shown in Figure 1. 


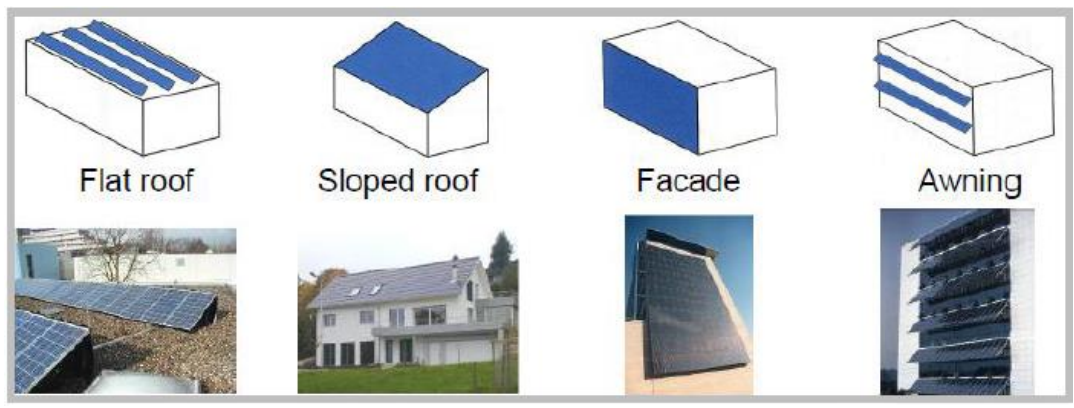

Figure 1: Type of PV panel integration to building Source: Pusat Tenaga Malaysia, 2007

Characteristics of BIPV:

- No use of land

- Use of synergies in the building

- Closest to point of consumption

- Substitutes the building element

\subsection{The current scenario of local BIPV application}

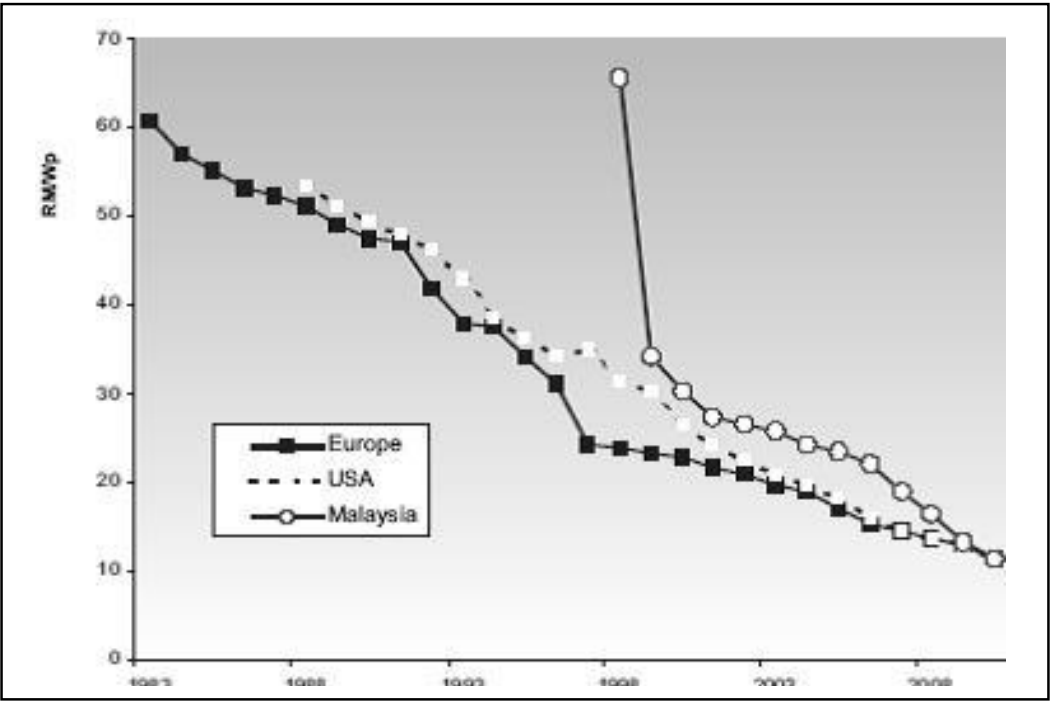

Figure 2: PV cost in Malaysia Europe and USA Source: Humm, 1999 
BIPV is a new PV application in Malaysia, although Malaysia already has extensive experiences on standalone PV of more than $2 \mathrm{MWp}$ of installed capacity, and adequate knowledge on grid-connected PV application of about 500kWp installed capacity (Sopian, 2005).

Compare to the world PV panel pricing, the PV price in Malaysia still high. Graph in Figure 2 shows the present and predicted cost comparisons of BIPV in Malaysia, Europe, and United States.

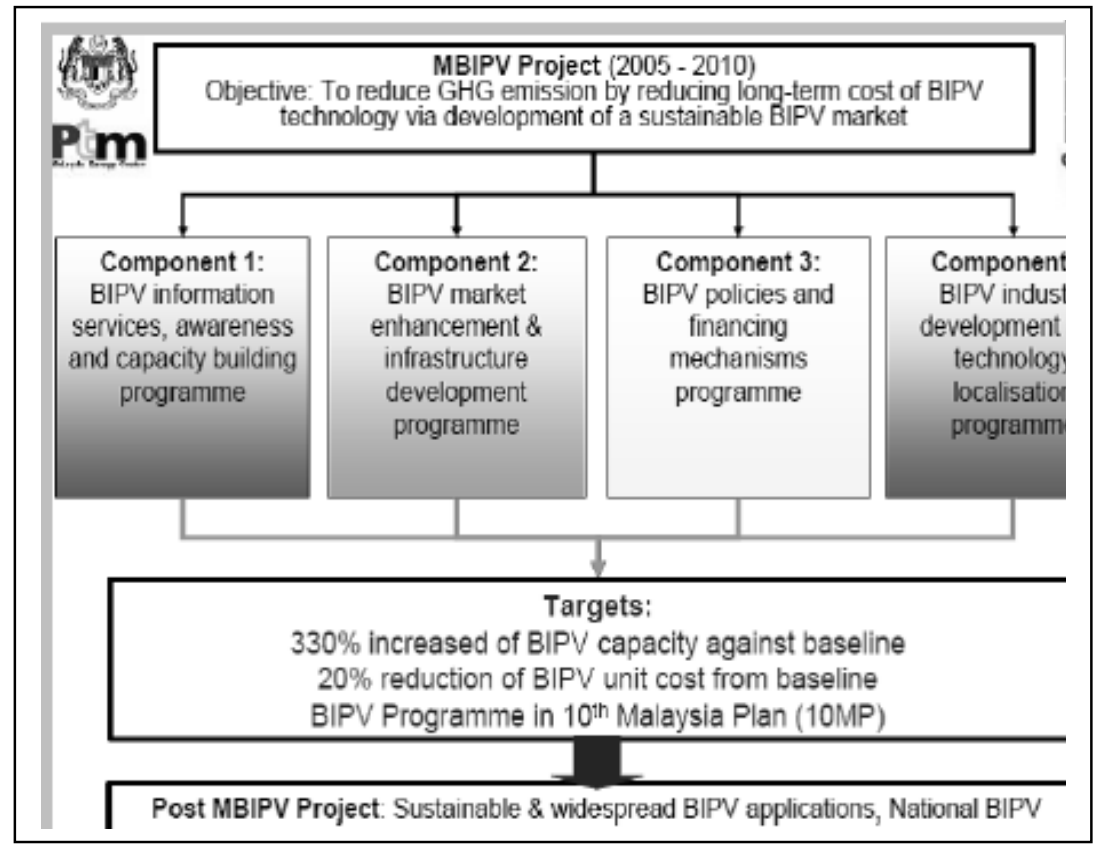

Figure 3: MBIPV project

Source: PTM, 2007

The main barrier to widespread of BIPV (or PV) application is the relatively high capital cost. This is largely contributed by:

- Miniscule local BIPV market;

- Lack of awareness and understanding of BIPV technology;

- Ignorance of BIPV added values;

- Adverse public perception on PV technology, (due to poor image of stand-alone PV systems) 
However, the high technology price can be reduced when there is a sustainable BIPV market. Unfortunately, a sustainable market cannot be established for as long as the economics of BIPV technology is unfavourable. Therefore, a concerted effort in the form of the national "MBIPV Project" an Renewable Energy (RE) project by Government of Malaysia under the 9th Malaysia Plan, with UNDP, GEF and private industry co-financing) is established. Figure 3 shows the main focus of the MBIPV project to develop a market that will lead towards long-term BIPV cost reduction. Initially, at the end of five-year period, the BIPV system cost is expected to reduce by $20 \%$ from the baseline cost.

\section{Factors influencing productivity of PV power generation}

They are several factors that influence PV panel performance at the roof as follow:

- Roof placement and orientation

- Roof design

- Tilt angle

- PV types

- Dust accumulation

\subsection{Methodology}

Before embarking on to site survey, few secondary data were collected through related literature review from books, articles in journals and internet sources as a guideline while conducting the research. Besides, these secondary data will also be used during analyzing the findings and as a proof if there is any controversial between opinions.

\section{Sample selection}

To ensure reliability of primary data collection through measurement, samples were chosen in one locality so as to limit the climatic variations. Few houses with BIPV installations in Shah Alam were identified, and their owners were approached for consent to carry out the survey. The 7 sample houses in 5 different areas chosen were Phase 2 Bandar Eco Setia, Setia Eco Park (Columba), Setia Eco Park (Draco), Setia Eco Park (Aquila), Section 9 Shah Alam, Section 11 Shah Alam and Bukit Jelutong, Shah Alam.

\section{Data collection}

A set of questions was drafted to collect data with respects to important parameters of BIPV application of the selected samples. Among the data gathered were the roof form, tilt angle, sun orientation, PV type, PV rating, PV module size and number of modules used. Measurement of solar intensity level was recorded using solar illumination level meter. And to ensure the reliability and to reduce variations in readings, all measurements of the 7 samples were done within a space of 2 hours (from $11.00 \mathrm{am}$ to $1.00 \mathrm{pm}$ ). Photographs of all samples were also taken for record. All data gathered were processed and tabulated for analysis.

\subsection{Findings and Discussions}


Graph in Figure 4 shows that Phase 2 Setia Eco Park and Setia Eco Villas which used Monocrystalline PV type generate more energy compared to other BIPV application which used Polycrystalline. Phase 2 Setia Eco Park is using a number $1100 \times 1300 \mathrm{~mm}$ size Monocrystalline PV panels that able to generate 10,650 kWh annually and Setia Eco Villas using a number of $1318 \times 994 \mathrm{~mm}$ size Monocrystalline PV panels that able to generate $10,400 \mathrm{kWh}$ per year. The differences in values are due to the different of total PV surface areas, tilt angle and orientation. The other three samples, however, using Polycrystalline and their power production is slightly lower even though the total PV surface areas are about the same.

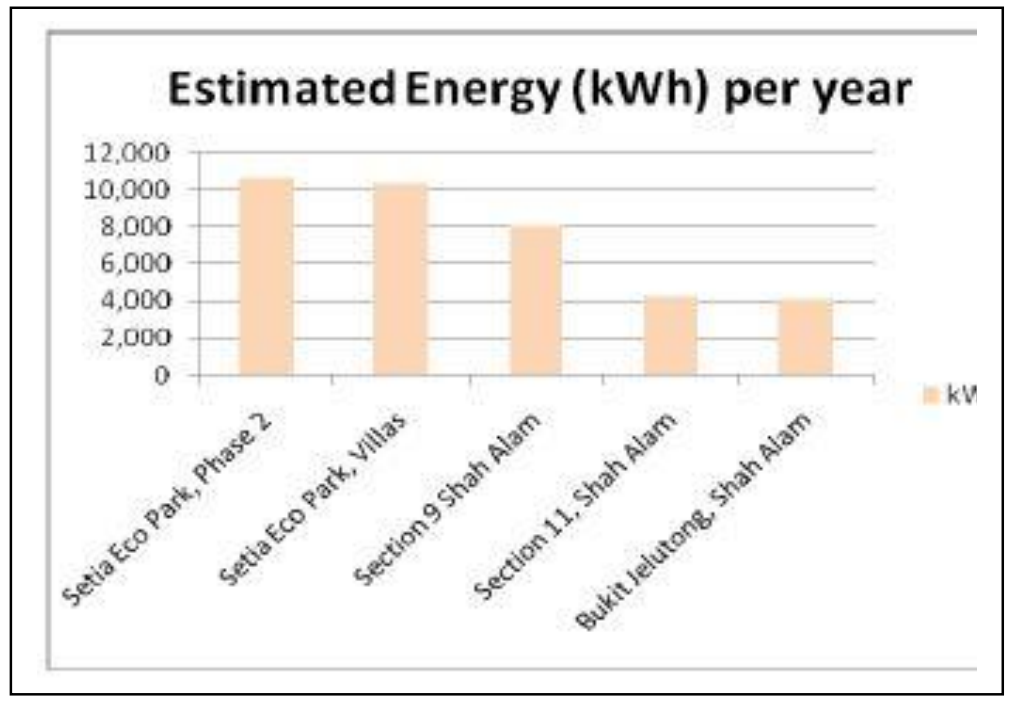

Figure 4: Energy production of BIPV samples

\section{Roof form, orientation and sun exposure hours}

Graph in Figure 5 shows the overall sun exposure hours of the samples. It was found that both roof form and orientation do influence the length of exposure hours that PV surfaces will get. Those roof forms which are flat and low tilt angles will experience about $8-10$ hours of sun, irrespective of the orientation. However, if the tilt angle is greater than $20^{\circ}$, building orientations do influence the sun exposure hours of PV surface areas, because some part of the PV surface could be under shaded by its own roof structure 


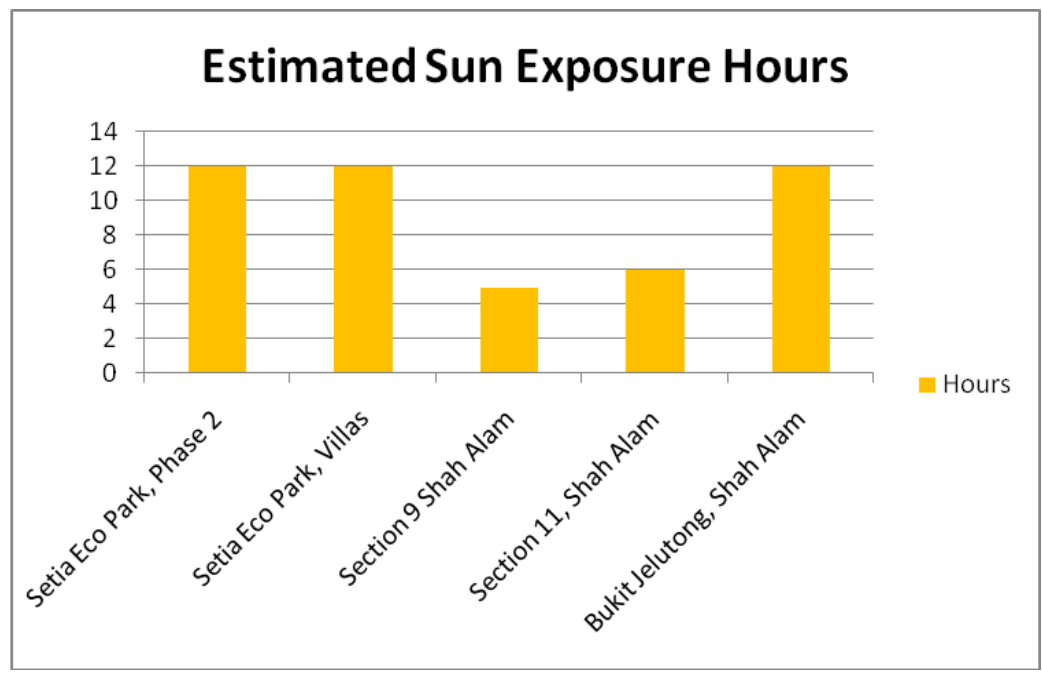

Figure 5: Sun exposure hours experienced by BIPV samples

Table 1: Overall description of the samples

\begin{tabular}{|c|c|c|c|c|c|c|c|c|}
\hline Sample & $\begin{array}{l}\text { Image and PV } \\
\text { Application } \\
\text { Type }\end{array}$ & PV Type & $\begin{array}{l}\text { PV } \\
\text { Surface } \\
\text { Area }\end{array}$ & $\begin{array}{l}\text { Direct } \\
\text { Sun } \\
\text { Exposu } \\
\text { re } \\
\text { Hours }\end{array}$ & $\begin{array}{l}\text { Energy } \\
\text { Generate } \\
d\end{array}$ & $\begin{array}{l}\text { Roof } \\
\text { Type } \\
\text { and } \\
\text { slope }\end{array}$ & $\begin{array}{l}\text { Orientati } \\
\text { on }\end{array}$ & $\begin{array}{l}\text { Observatio } \\
\mathrm{n} \text { and } \\
\text { comments }\end{array}$ \\
\hline $\begin{array}{l}\text { Bandar } \\
\text { Eco } \\
\text { Setia, } \\
\text { Phase 2 }\end{array}$ & Retrofitted & $\begin{array}{l}5.28 \\
\text { kWp } \\
\text { Mono- } \\
\text { Crystallin } \\
\text { e, } \\
\text { Sunterh }\end{array}$ & $\begin{array}{l}1100 x \\
1300 \mathrm{~m} \\
\mathrm{~m} \times 30 \\
\text { nos. }= \\
42.9 \mathrm{~m}^{2}\end{array}$ & $\begin{array}{l}8-10 \\
\text { hours }\end{array}$ & $\begin{array}{l}29.172 \\
\text { kWh per } \\
\text { day } \\
\text { exposure }\end{array}$ & $\begin{array}{l}\text { Pitch } \\
\text { roof } \\
@ \\
15 .\end{array}$ & $\begin{array}{l}\text { Roof } \\
\text { surface } \\
\text { facing } \\
\text { north } \\
\text { and } \\
\text { couth }\end{array}$ & $\begin{array}{l}\text { Good roof } \\
\text { design and } \\
\text { considering } \\
\text { sun path } \\
\text { for PV } \\
\text { inctallation }\end{array}$ \\
\hline $\begin{array}{l}\text { Setia } \\
\text { Eco } \\
\text { Park, } \\
\text { Columb } \\
\text { a } \\
\end{array}$ & Integrated & $\begin{array}{l}\mathrm{kWp} \\
\text { Mono- } \\
\text { corystallin } \\
\mathrm{e}_{\text {; }}\end{array}$ & $\begin{array}{l}1318 \mathrm{x} \\
994 \mathrm{~mm} \\
\mathrm{x} 32 \\
\text { nos. }= \\
41.9 \mathrm{~m}^{2}\end{array}$ & $\begin{array}{l}8-10 \\
\text { hours }\end{array}$ & $\begin{array}{l}28.5 \\
\text { kWh per } \\
\text { day } \\
\text { exposure }\end{array}$ & $\begin{array}{l}\mathrm{RC} \\
\text { Flat } \\
\text { roof }\end{array}$ & $\begin{array}{l}\text { Roof } \\
\text { surface } \\
\text { facing } \\
\text { the sky }\end{array}$ & $\begin{array}{l}\text { Flat roof } \\
\text { offers } \\
\text { maximum } \\
\text { power } \\
\text { generation }\end{array}$ \\
\hline
\end{tabular}




\begin{tabular}{|c|c|c|c|c|c|c|c|c|}
\hline $\begin{array}{l}\text { Setia } \\
\text { Eco } \\
\text { Park, } \\
\text { Draco }\end{array}$ & 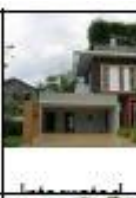 & $\begin{array}{l}4.2 \mathrm{kWp} \\
\text { Mono- } \\
\text { rystallin } \\
\text { Solarworl } \\
\text { d } 175\end{array}$ & $\begin{array}{l}1318 \mathrm{x} \\
994 \mathrm{~mm} \\
\mathrm{x} 24 \\
\text { nos. }= \\
27.1 \mathrm{~m}^{2}\end{array}$ & $\begin{array}{l}8-10 \\
\text { hours }\end{array}$ & $\begin{array}{l}18.4 \\
\text { kWh per } \\
\text { day } \\
\text { exposure }\end{array}$ & $\begin{array}{l}\text { RC } \\
\text { Flat } \\
\text { roof }\end{array}$ & $\begin{array}{l}\text { Roof } \\
\text { surface } \\
\text { facing } \\
\text { the sky }\end{array}$ & \multirow{2}{*}{$\begin{array}{l}\text { through } \\
\text { longer sun } \\
\text { exposure } \\
\text { hours, } \\
\text { however, } \\
\text { not suitable } \\
\text { for } \\
\text { Malaysian } \\
\text { climate for } \\
\text { it is prone } \\
\text { to leaking }\end{array}$} \\
\hline $\begin{array}{l}\text { Setia } \\
\text { Eco } \\
\text { Park, } \\
\text { Aquila }\end{array}$ & & $\begin{array}{l}78 \\
\text { kWp } \\
\text { Mono- } \\
\text { ofystallin } \\
\text { Solanunel }\end{array}$ & $\begin{array}{l}1318 \mathrm{x} \\
994 \mathrm{~mm} \\
\times 33 \\
\text { nos. }= \\
43.2 \mathrm{~m}^{2}\end{array}$ & $\begin{array}{l}8-10 \\
\text { hours }\end{array}$ & $\begin{array}{l}29.4 \\
\text { kWh per } \\
\text { day } \\
\text { exposure }\end{array}$ & $\begin{array}{l}\mathrm{RC} \\
\text { Flat } \\
\text { roof }\end{array}$ & $\begin{array}{l}\text { Roof } \\
\text { surface } \\
\text { facing } \\
\text { the sky }\end{array}$ & \\
\hline $\begin{array}{l}\text { Section } \\
9 \\
\text { Shah } \\
\text { Alam }\end{array}$ & Integr & $\begin{array}{l}\text { Poly- } \\
\text { crystallin } \\
\mathrm{e} \\
4.80 \\
\mathrm{kWp}\end{array}$ & $52.4 \mathrm{~m}^{2}$ & $\begin{array}{l}3-5 \\
\text { hours }\end{array}$ & $\begin{array}{l}22.1 \\
\text { kWh per } \\
\text { day } \\
\text { exposure }\end{array}$ & $\begin{array}{l}\text { Pitch } \\
\text { roof } \\
@ \\
35^{\circ}\end{array}$ & $\begin{array}{l}\text { Roof } \\
\text { surface } \\
\text { facing } \\
\text { east and } \\
\text { west }\end{array}$ & $\begin{array}{l}\text { PV } \\
\text { installed on } \\
\text { the steep } \\
\text { slope } \\
\text { reduce } \\
\text { nroductivity }\end{array}$ \\
\hline $\begin{array}{l}\text { Section } \\
11, \\
\text { Shah } \\
\text { Alam }\end{array}$ & Retrofitted & $\begin{array}{l}\text { Poly- } \\
\text { crystallin } \\
\mathrm{e} \\
3.12 \\
\mathrm{kWp}\end{array}$ & $42.9 \mathrm{~m}^{2}$ & $\begin{array}{l}4-6 \\
\text { hours }\end{array}$ & $\begin{array}{l}11.5 \\
\text { kWh per } \\
\text { day } \\
\text { exposure }\end{array}$ & $\begin{array}{l}\text { Pitch } \\
\text { roof } \\
@ \\
30^{\circ}\end{array}$ & $\begin{array}{l}\text { Roof } \\
\text { surface } \\
\text { facing } \\
\text { east and } \\
\text { west }\end{array}$ & $\begin{array}{l}\text { PV } \\
\text { installed on } \\
\text { the east } \\
\text { and west } \\
\text { facing roof }\end{array}$ \\
\hline $\begin{array}{l}\text { Bukit } \\
\text { Jeluton } \\
g\end{array}$ & prez & $\begin{array}{l}\text { Poly- } \\
\text { crystallin } \\
\mathrm{e} \\
4.80 \\
\mathrm{kWp}\end{array}$ & $23.3 \mathrm{~m}^{2}$ & $\begin{array}{l}8-10 \\
\text { hours }\end{array}$ & $\begin{array}{l}11.2 \\
\text { kWh per } \\
\text { day } \\
\text { exposure }\end{array}$ & $\begin{array}{l}\text { Pitch } \\
\text { roof } \\
@ \\
25^{\circ}\end{array}$ & $\begin{array}{l}\text { Roof } \\
\text { surface } \\
\text { facing } \\
\text { north } \\
\text { and } \\
\text { couth }\end{array}$ & $\begin{array}{l}\text { PV } \\
\text { installed on } \\
\text { the steep } \\
\text { slope } \\
\text { reduce } \\
\text { nenduntivity }\end{array}$ \\
\hline
\end{tabular}

\subsection{Conclusion}

It was found that more energy can be harnessed by flat roof and pitch roof with gentle slope because the surface of PV modules facing the solar radiation almost perpendicular where it gets almost $100 \%$ solar intensity of the day. This is clearly shown by the BIPV application on houses at Eco Setia Park where they registered at an average of 10,450 kWh annually.

From the findings it was found that the pitch roof with low slope facing to north and south can have a longer sun exposure hour, hence producing more electrical energy. However, few sample houses even though the orientation is north-south but their roof form has slope facing east-west, therefore limit the solar exposure hour by half, hence lest power generation. It was also found that the roof form and geometrical shape have influence on the surface area, therefore limit the number of PV modules that can be installed. Theoretically, the more modules can be installed, the bigger PV surface area, thus greater amount of power generated.

Comparatively, PV types do have direct influence on the power production, but other factors such as exposure hours, solar intensity, shadow, dirt accumulation, and tilt angle can 
give different values. Monocrystalline performs better than polycrystalline, however it is more expansive, but cost is not discuss in this research. Future research on BIPV should focus on

\section{Acknowledgement}

The authors would like to thank Universiti Teknologi MARA and the Faculty of Architecture, Planning and Surveying for the infrastructural support.

\section{References}

Haris, A.H. (2008). "A Unique Policy Development Outside Europe: The Example of Malaysia," MBIPV Project Malaysia Energy Centre (PTM), 2nd International Conferences on Solar Pho- tovoltaic Investments, Frankfurt am Main, Germany, 2008.

How Photovoltaic Work. Retrieved on $30^{\text {th }}$ June 2013 from http://www.montanagreenpower.com/solar/curriculum/lesson6.pp

Humm, O. and Toggweiler, P. (1993). Photovoltaic in Architecture, Birkhauser Verlag.

Pusat Tenaga Malaysia (2007). Sustainable Development Using Solar Energy, paper presented at the seminar sustainable development 7 August 2007 Kuala Lumpur

PV Panel Productivity. Retrieved on $30^{\text {th }}$ June 2013 from https://sites.google.com/site/reeetech/mbipv/photovoltaicarray-system-design

Renewable energy. Retrieved on $30^{\text {th }}$ June 2013 from http://en.wikipedia.org/wiki/Renewable_energy

Sopian,K., Haris, A.H., Rouss, D. and M.A.Yusof , M.H. (2005). Building Integrated Photovoltaic (BIPV) in Malaysia - Potential, Current Status Strategies for Long Term Cost Reduction, Journal of science and technology vision, vol 1 may 2005 pp 40-44.

Sopian, K. and Othman M.Y. (1992). Estimates of monthly average daily global solar radiation in Malaysia, Renewable Energy, vol 2(3).pp 319-325.

Sustainable Design. Retrieved on 30 th June 2013 from http://en.wikipedia.org/wiki/Sustainable_design 